Acta Horticulturae et Regiotecturae 2

Nitra, Slovaca Universitas Agriculturae Nitriae, 2015, pp. 49-52

\title{
COMPOSITION ANALYSIS OF MUNICIPAL SOLID WASTE AT A UNIVERSITY DORMITORY
}

\author{
Anna BÁREKOVÁ*, Zuzana FRANEKOVÁ
}

Slovak University of Agriculture in Nitra, Slovak Republic

\begin{abstract}
The paper represents a waste composition study that was conducted at the Mladost' dormitory of the Slovak University of Agriculture (SUA) in Nitra. The aim of the study was to determine the amount and composition of waste generated in the dormitory and to provide recommendations for enhancing the recycling rates and to improve the overall sustainability of waste management in the dormitory. The analysed solid waste was separated into organics, papers, plastics, glass, metals, cardboard beverage packaging (tetrapak), electronic waste (e-waste), and others. The estimated annual average quantity of waste generated per student of the dormitory is $38 \mathrm{~kg}$. The composition of generated solid waste is as follows: paper (6\%), glass (26\%), plastic (9\%), metal $(4 \%)$, organic $(28 \%)$, tetrapak $(2 \%)$, e-waste $(1 \%)$ and other waste $(24 \%)$. Potential recycling rate of generated waste is $76 \%$. Composting is the most sustainable method to convert organic waste into valuable compounds and to reduce the waste disposed into landfills.
\end{abstract}

Keywords: municipal solid waste, waste generation, waste composition analysis, university dormitory

Landfilling is still the most frequent method of municipal waste management in Slovakia. Only $10 \%$ of municipal solid waste (MSW) is annually recycled (Lackóová et al., 2013). Effective solid waste management requires a complete understanding of the composition of a waste stream as well as activities that determine its generation in the first place (Smyth et al., 2010).

To enable more efficient separate waste collection at the dormitory Mladost' of the SUA in Nitra, we conducted quantitative composition analyses of the waste generated by accommodated students in 2014. The results of the analyses illustrate the potential for recycling of generated waste and represent basis for drawing up proposals for measures leading to more efficient waste management directly at the originator (Báreková and Kaufman, 2012). They also have an important role in the design of an integrated solid waste management system in particular collecting areas (Gidakaros et al., 2006; Sklenár and Hlavačková, 2005).

A survey which was conducted by Franeková and Báreková (2013) among students accommodated in the dormitory Mladost' showed that the selective collection of waste in the given dormitory has many shortcomings - even $58 \%$ of surveyed students expressed dissatisfaction with it. Only $42 \%$ of the respondents used containers for collection of paper and plastic and $70 \%$ of the surveyed students declared that the containers for separate collection should be placed on each floor. Regarding organic waste, $51 \%$ of the respondents would use composters, if they were available nearby the dormitory.

\section{Material and methods}

Nitra has a population of 80,524 (as of December 31, 2014). The dormitory Mladost' of SUA in Nitra has 417 rooms, used for accommodation of 1,166 students. In addition, there is also a dining area and a dayroom. Separate waste collection at the dormitory was introduced in April 2012. The containers for the collection are provided by Green Wave Recycling Limited (GWR Ltd.). At present, in the entrance hall of the dormitory there are placed four containers for plastic, two containers for paper and two containers for glass. The capacity of each of them is 240 litres. Collecting of residual municipal waste from the dormitory is provided by the Nitra town. Near the dormitory there are currently located 5 containers for MSW with a volume of 1,100 litres.

After studying several methodologies of quantitative waste analyses, we employed the methodology of The Scottish Environment Protection Agency (SEPA, 2008), which we adjusted for our conditions. The analyses were realized in the calendar year 2014 in all seasons. They illustrate the composition of representative samples of MSW over one reference year. According to the methodology, we collected the samples directly at the source (at the rooms of students) into the indicated bags and then weighted them. Sorting into categories was carried out by the students themselves, but sometimes we had to final-sort them. The analysed waste came from 21 students accommodated in six rooms. All these four seasonal analyses were conducted over one week. It also included weekends, when the number of students in the room usually declined. 


\section{Results and discussion}

Summary results of quantitative analyses of waste composition at the dormitory Mladost' (Table 1) show that the total mass of the analysed waste was almost $100 \mathrm{~kg}$ while the waste was sorted into eight categories. The sorted components with the highest representation were glass $(25.73 \mathrm{~kg})$ and organic waste $(27.94 \mathrm{~kg})$. Materials included in the organic waste contain only non-recyclable paper and food waste suitable for composting.

Table 1 Waste composition analysis in 2014 according to total wet weight

\begin{tabular}{|l|c|}
\hline Material & Total weight in kg \\
\hline Paper & 6.25 \\
\hline Plastics & 8.85 \\
\hline Glass & 25.73 \\
\hline Metals & 3.54 \\
\hline Tetrapak & 1.92 \\
\hline Organic waste & 27.94 \\
\hline Electronic waste & 0.83 \\
\hline Others waste & 23.33 \\
\hline Total & 98.36 \\
\hline
\end{tabular}

From the results of the analyses, we calculated the estimated annual quantities of the waste fractions (Table 2) originating in the reporting dormitory. These are the potential weights of the components in the case of complete separation. Since the dormitory is not actively occupied throughout the year, we included only 230 days of the year in the calculation. Operating records of the company GWR Ltd. (which provides a collection of sorted plastic and paper at SUA) indicate that at the dormitory there is annually collected $544.5 \mathrm{~kg}$ of paper and $1231 \mathrm{~kg}$ of plastics on average. It is only about a quarter of our estimated potential quantities (Table 2).

The percentage of the analysed components of the waste (Figure 1) shows that only $24 \%$ of the generated waste cannot be materially recovered on average (i.e. other waste). The collection and subsequent recycling for all other

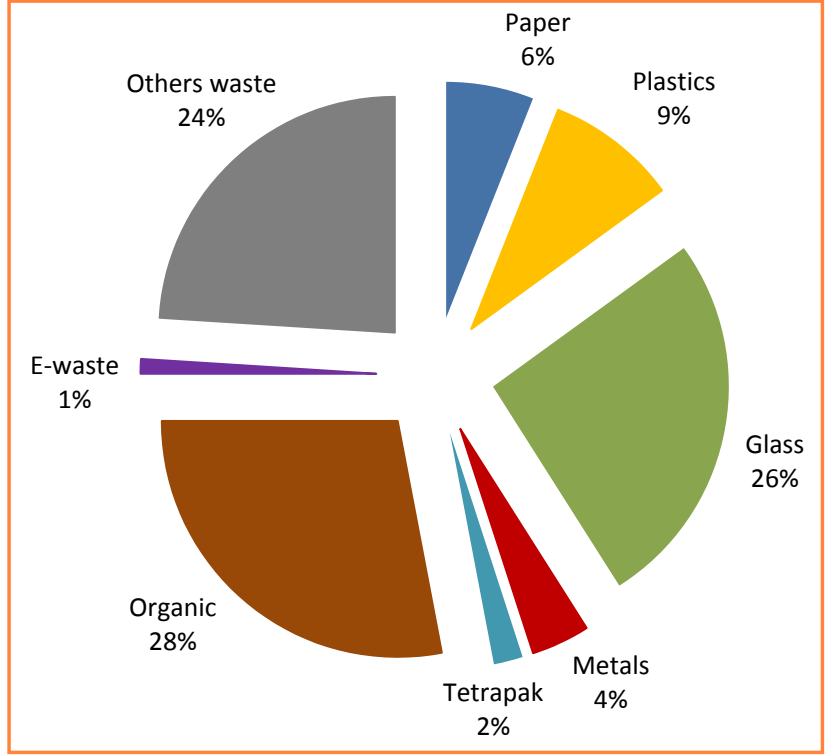

Figure 1 Waste composition analysis (2014), wet weight

classified components are ensured by the town of Nitra. Organic waste has the highest proportion (28\%), confirming our belief that it is necessary to ensure separate collection or processing of this waste fraction (previously landfilled) at the dormitory. In these given conditions, two variants are available:

- To establish a community composting nearby the dormitory.

- To request containers for organic matter to engage in its collection system in the town of Nitra with subsequent treatment in municipal composting plant.

Both solutions mean conversion of food waste into compost.

Benefits of composting (Tiew et al., 2011) are shown below:

- Reduced landfill space.

- Reduced surface and groundwater contamination.

- Reduced methane emissions.

- Reduced transportation costs.

- Reduced air pollution from burning waste.

- More flexible overall waste management.

- Enhanced recycling of materials.

- Little capital and operating costs.

Table 2 Annual waste production estimation for the dormitory Mladost' in $\mathrm{kg}$

\begin{tabular}{|l||c|c|}
\hline Waste material & Estimated production per resident in kg per year & Estimated production per dormitory in kg per year \\
\hline Paper & 2.44 & 2845 \\
\hline Plastics & 3.46 & 4032 \\
\hline Glass & 10.06 & 11733 \\
\hline Metals & 1.39 & 1619 \\
\hline Tetrapak & 0.75 & 872 \\
\hline Organic waste & 10.93 & 12748 \\
\hline Electronic waste & 0.33 & 383 \\
\hline Others waste & 9.13 & 10641 \\
\hline Total & $\mathbf{3 8}$ & $\mathbf{4 4 8 7 2}$ \\
\hline
\end{tabular}




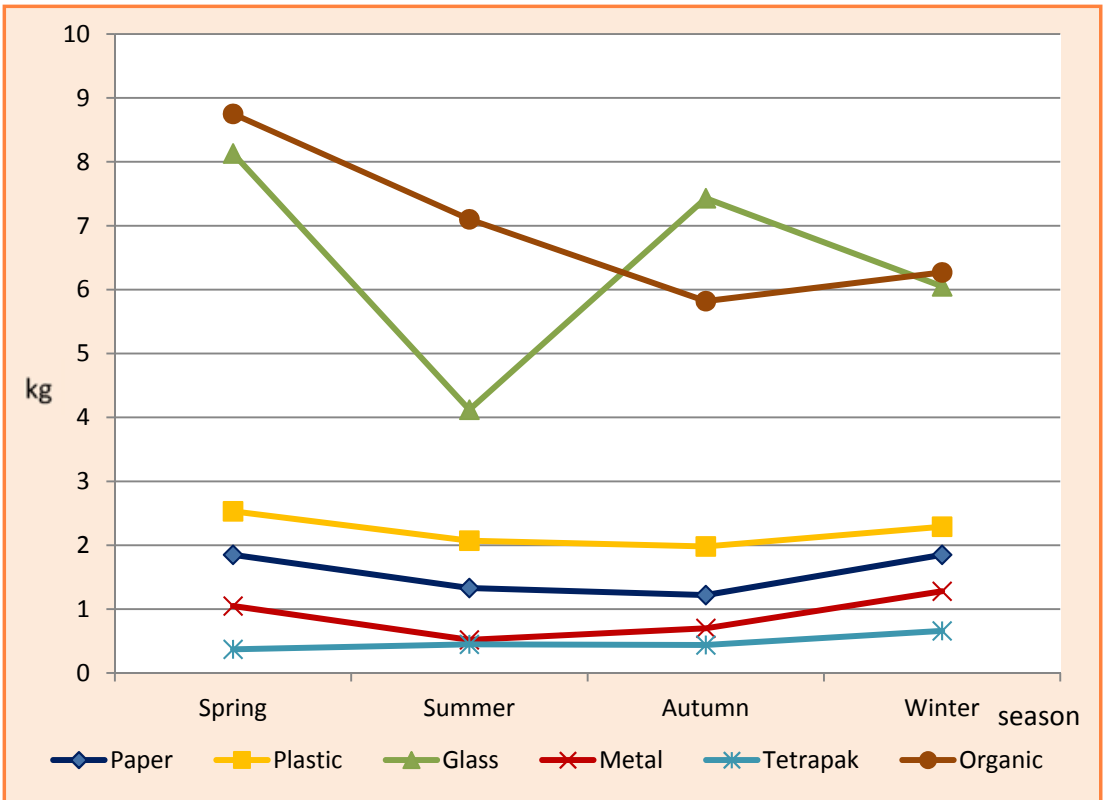

Figure 2 Waste composition analysis shows seasonal variation of recyclable fractions, wet weight

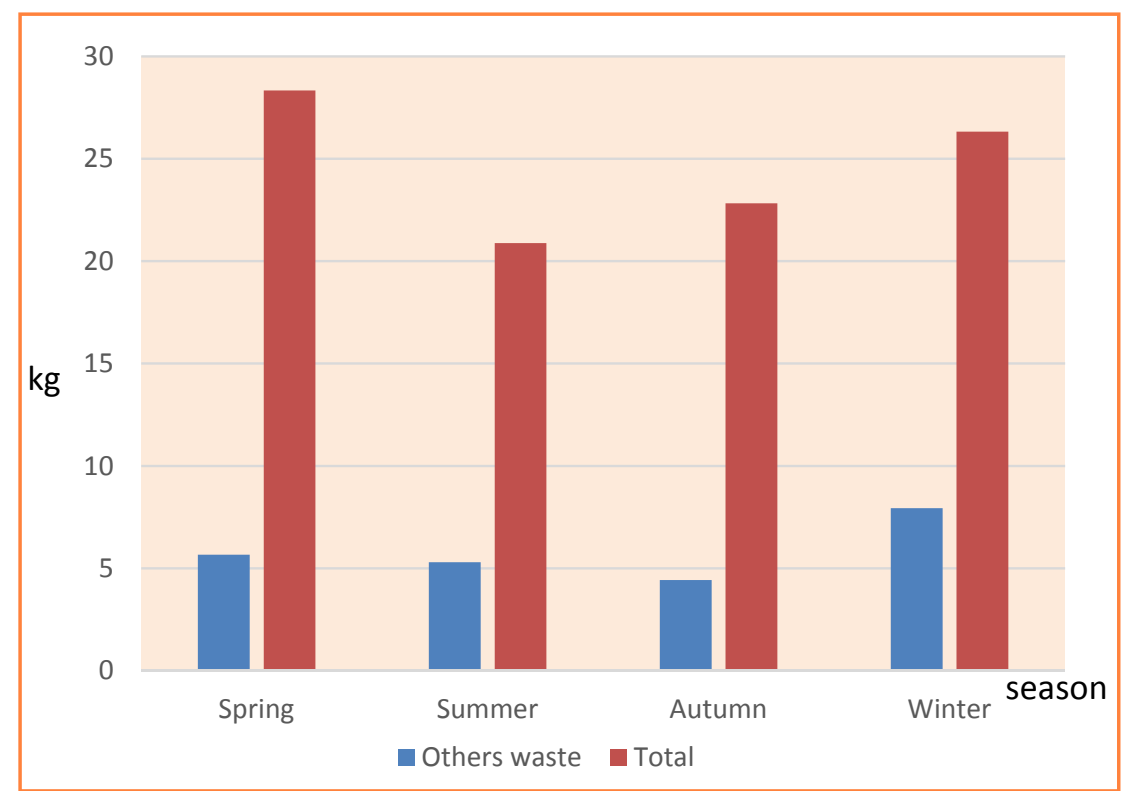

Figure 3 Waste composition analysis shows seasonal variation of nonrecyclable fraction and total amount of waste, wet weight

Existing risk of high contamination (over $2 \%$ ) of separated organic waste can cause difficulties in the composting process. Undesirable ingredients are often non-compostable plastic bags and organic waste such as remains of meat and bones (Stejskal, 2010). Therefore, of bio-waste more attention must be paid to raising awareness and to public education of waste producers (in this case of students) during implementation of the collection.

Evaluation of the results of analyses allows us to estimate the anticipated seasonal changes in the amount of individual components produced at the dormitory (Figure 2 and 3). The highest variability is demonstrated precisely in the components with the highest representation, i.e. organic waste and glass. For other recyclable materials, there was an insignificant seasonal change in the resulting amount. However, it must be noted that analysed glass waste consisted primarily of alcoholic beverages packaging. This is probably also the cause of a significant decrease in this component in the summer analysis that was conducted during the examination period.

The graph in Figure 3 shows the evolution of total amount of waste produced in the course of weekly analyses compared to the amount of non-recyclable fraction. The highest proportion of this component in the total waste was in winter $(30 \%)$, and in autumn was its representation in the analysed waste the lowest (19.4\%). Thus, we can conclude that the share of materially recoverable waste in the total waste production at the dormitory ranges from 70 to $80 \%$ during the year.

Our results confirm the data from Table 3, where we compare them with the waste characterization studies that were conducted at dormitories of the University Kebangsaan Malaysia (UKM) and at the Prince George campus of the University of Northern British Columbia (UNBC) in Canada. To simplify, waste was classified into three waste streams (recyclable,

Table 3 Percentages (by weight) of the recyclable and compostable waste components (comparison with other universities)

\begin{tabular}{|l||c|c|c|}
\hline Waste stream & Dormitory Mladost' of the SUA & Dormitories of the UKM* & Prince George campus of the UNBC** \\
\hline Recyclable & $48 \%$ & $22.2 \%$ & $49.97 \%$ \\
\hline Compostable & $28 \%$ & $51.6 \%$ & $21.61 \%$ \\
\hline Non-recyclable & $24 \%$ & $26.2 \%$ & $28.42 \%$ \\
\hline Total & $100.0 \%$ & $100 \%$ & $100 \%$ \\
\hline
\end{tabular}

Source: *Tiew et al., 2011; **Smyth et al., 2010 
compostable and non-recyclable waste). In all three universities, a non-recyclable fraction was represented by 20 to $30 \%$. The difference was only in the proportion of recyclable and compostable materials, which probably reflects climatic conditions, food habits and living standard of students in the compared states.

\section{Conclusion}

In summary of the study of waste composition, it can be said that the SUA campus could restructure its waste management in the dormitories because almost $76 \%$ of the produced waste is recyclable or compostable (Figure 1). There is a high potential (28\%) for converting the waste into fertilizers that can be used for landscaping at the SUA rather than dumped into landfills.

Our main recommendations are:

- To introduce the collection of organic waste at the dormitories (according to our estimated annual production of organic waste is about $4000 \mathrm{~kg}$ of compost in the dormitory Mladost').

- To improve the availability of containers for separate collection (to place containers for components that have a high percentage on each floor - glass, organic waste, plastics, paper).

- To ensure understandable indicating of containers.

- To take care of public education (regularly inform students about the importance of waste separation at the dormitory and about its practice).

\section{References}

BÁREKOVÁ, A. - KAUFMAN, P. 2012. Proposal for a model composition of MSW in a rural area. In Acta horticulturae et regiotecturae, vol. 15, 2012, special number, pp. 13-15. ISSN 1335-2563.

FRANEKOVÁ, Z. - BÁREKOVÁ, A. 2013. Zavádzanie separovaného zberu odpadu $v$ prostredí vysokoškolského internátu. In Recenzovaný zborník z medzinárodnej vedeckej konferencie doktorandov a mladých vedeckých pracovníkov "Veda mladých 2013". Jevíčko, 2013. s. 357-362. ISBN 978-80-552-1081-0.

GIDAKAROS, E. et al. 2006. Municipal solid waste composition determination supporting the integrated solid waste management system in the island of Crete. In Waste Management, vol. 26, 2006, pp. 668-679. ISSN 0956-053X.

LACKÓOVÁ, L. et al. 2013. Environmental impacts in Slovak Republic. In ENVIRO 2013. $1^{\text {st }}$ ed. 1 CD-ROM (195 s.). Nitra : SPU, 2013, pp. 107113. ISBN 978-80-552-1101-5.

SEPA (Scottish Environmental Protection Agency). 2008. National methodology of household waste analysis in Scotland.

SKLENÁR, Š. - HLAVAČKOVÁ, V. 2005. Analysis of the share of packaging in municipal waste. In Acta horticulturae et regiotecturae, vol. 8, 2005, special number, pp. 285-288. ISSN 1335-2563.

SMYTH, D. et al. 2010. Reducing solid waste in higher education: The first step towards 'greening' a university campus. In Resources, Conservation and Recycling, vol. 54, 2010, no. 11, pp. 1007-1016. ISSN 0921-3449.

STEJSKAL, B. 2010. Assessment of current quality of biodegradable municipal waste separated by residents of Kroměřiž. In Acta univ. agric. et silvic. Mendel. Brun., vol. 58, 2010, no. 4, pp. 209-212. ISSN 1211-8516.

TIEW, K. et al. 2011. Composition of Solid Waste in a University Campus and its Potential for Composting. In International Journal on Advanced Science, Engineering and Information Technology, vol. 1, 2011, no. 6, pp. 675-678. ISSN 2088-5334. 